\title{
THE EFFECT OF STRATEGIC HUMAN RESOURCES COMPETENCY AND LOGISTIC MANAGEMENT ON ORGANIZATIONAL PERFORMANCE MEDIATED BY STRATEGIC LEADERSHIP
}

\author{
*Toto Dwijaya Saputra ${ }^{1}$, Kusnadi ${ }^{2}$ \\ ${ }^{1}$ Universitas Trisakti, Jakarta, Indonesia \\ ${ }^{2}$ STIMA IMMI, Jakarta, Indonesia \\ *Coresponding author. \\ E-mail addresses: toto_dwijaya34@yahoo.com
}

\begin{abstract}
ARTICLE INFO
Article history:

Received:

21 August 2021

Accepted:

15 October 2021

Available online:

26 November 2021

ABSTRACT

This study aims to investigate the effect of Strategic Human Resources Competency and Logistic Management on Organizational Performance mediated by Strategic Leadership. The methodology used in this study is explanatory research with hypothesis testing to test the seven hypotheses proposed in the study and the population and sample are 180 who serve in Koarmada I. Data collection uses questionnaires and technical data analysis uses SEM (Structural Equation Modeling). Based on the results of hypothesis testing and the discussion in the previous chapter, in general the conclusion is that there are Strategic Human Resources Competence, Logistics Management on Organizational Performance mediated by Strategic Leadership This study shows that Strategic Human Resources Competency and Logistics Management on Organizational Performance are mediated by Strategic Leadership either directly or indirectly. This research is a useful tool to improve Organizational Performance by increasing Strategic Human Resources Competency and Logistics Management and Strategic Leadership. This research model refines the overall understanding that there are direct and indirect effects of Strategic Human Resources Competence, Logistics Management on Organizational Performance mediated by Strategic Leadership.
\end{abstract}

Keyword: Strategic Human Resources Competence, Logistic Management and Organizational Performace.

\section{INTRODUCTION}

Currently, the existence of an advanced base on Natuna Besar Island, namely Lanal Ranai, is quite strategic, because warships from the South China Sea to the Indian Ocean will definitely cross the waters of the Natuna Sea. In addition, of course, Lanal Ranai can be a representative base for support for the operations of the Indonesian Navy warships in the Natuna Sea and the EEZ of the North Natuna Sea. However, it should also be noted that the existence of the forward base must also be supported by the main base. The base base should have the ability to cover the Indian Ocean and shipping lanes to the South China Sea and the Pacific Ocean. One of the approaches to the Indian Ocean is the Sunda Strait and this strait is not far from Jakarta. The Sunda Strait is connected to the Java Sea, the Malacca Strait, the Natuna Sea and the South China Sea. This narrow 
water area is also one of the regular crossing points for Australian warships, particularly those from Fleet Base West HMAS Stirling near Perth, Western Australia. In addition, warships from the United States, India and China regularly pass in the waters that separate the islands of Sumatra and Java. Currently, the Koarmada I Base is still mixed with commercial shipping at the Tanjung Priok Port, Jakarta, so that operational security is not maintained and guaranteed. The Koarmada I base in Pondok Dayung, Tanjung Priok is also not integrated with the Mako Koarmada I which is located in the center of the city center of Jakarta, so coordination between the leadership and operational elements takes time because it is constrained by distance.

From the logistical aspect, the main base of Koarmada I in Pondok Dayung, Tanjung Priok also does not have adequate facilities to support the continuity of warship operations. The currently available anchorage facilities can only accommodate warships with dimensions of 100 meters and below, and even then, the number and length of the piers are limited. Likewise, the limited area of the wharf pool, where in the middle of the pier pool is also a passage for non-warship ships, thus affecting the operational security of warships. The anchoring facilities have also not been able to fully provide onshore electricity support to the warships that lean on, so the warships are forced to rely on supplies from their own diesel generators. This of course is a waste of fuel consumption of warships. The warship maintenance and repair facility (Fasharkan) owned by Pangkalan Pondok Dayung is not in accordance with the needs, because it can only serve certain types of warships with dimensions below 40 meters. The warships with dimensions above 40 meters cannot be served by warship maintenance and repair facilities. With these limitations, maintenance and repair activities for warships with dimensions above 40 meters are carried out in shipyards owned by third parties. Fasharkan has not been able to support the implementation of mid-level maintenance of warships. In fact, as time goes by, now the number of Koarmada I warships with dimensions above 40 meters is increasing, such as frigates, LST and BCM.

Regarding the supply facilities, basically in Jakarta, warehousing is available, such as warehouses for food supplies, personal and field equipment (Kaporlap), weapons and ammunition, communication and electronic equipment (alkomlek), medical supplies and so on. However, until now the location of the warehouse is not yet fully within the Pondok Dayung Base, so it has not been fully effective in supporting the existence of the base. Most of the warehousing is outside the Pondok Dayung Base area, even in the middle of a crowded city. The development of the Navy's strength cannot be separated from the construction of a base that functions as a home base to support the continuity of an operation. In a logistical sense, the base serves as a point of support for supplies, repairs and protection for elements of the operation. The base in the sense of logistical support is one of the most important operational functions, because without logistics infrastructure, it is very difficult to carry out operations. Therefore, logistics must be an integral part of a military operation. The success of military operations carried out by the TNI, especially the Navy, will not achieve the stated goals if it is not supported by adequate logistics. The development of the Naval logistics sector is one part of the development of the Navy which is domiciled in the same position, interacts and supports each other and depends on other parts of the Navy's development, so as to create synergy in realizing the capabilities and strengths of the Navy. The success of the development of the Navy's logistics sector will determine the success of all the Navy's capability development activities (Binpuan) which are presented in the form of the use of the Navy's force (Gunkuat).

Related to logistics, Kasal Skep No. Skep/372/III/2007 dated March 14, 2007 regarding standardization of Navy Bases must have the following facilities; 1) Anchoring Facilities (Faslabuh). Faslabuh standards are the availability of docks equipped with standard facilities that are continuously improved in quantity and quality to the level of capability and ideal readiness support to support the integration of SSAT 2) Maintenance and Repair Facilities (Fasharkan). Fasharkan is required to have various supporting facilities for the maintenance and repair of warships. Even for certain types of warships, Fasharkan is required to have intermediate level maintenance capabilities. 3) Supplies Facilities (Fasbek). Namely the availability of warehousing facilities equipped with tools and able to store logistical support. The warehousing includes warehouses for food supplies, personal and field equipment (kaporlap), weapons and ammunition supplies, communication and electronic equipment (alkomlek), health supplies and so on. 4) Personnel Care Facilities (Faswatpers). are residences such as official housing (Rumdis) and messing, hospitals (Rumkit) and various facilities to support health, sports and recreation, worship and training 5) Base Development Facilities (Fasbinlan). includes public facilities such as offices and transportation service facilities in the form of transportation of goods and personnel, as well as by post by land, sea and air to the area of operation. 
In order to support military operations, logistical support is crucial enough to protect and raise the party's own combat power so that the culmination point (fatigue) is not reached before the operational or strategic objectives provided have been achieved. Logistical support is directly related to operational logistics, where without a good logistics infrastructure, combat forces cannot sustainably survive. In general, logistics includes all aspects of military operations related to the preparation and planning, procurement, storage, movement, distribution, maintenance, evacuation and shifting of materials, movement, evacuation and transport of personnel to hospitals, procurement or construction, maintenance, operations and shifts. facilities and procurement of equipment or services. Logistics can be divided into three categories, namely tactical, strategic and operational. Logistics. The operational logistics extends from the initial base to the combat support units on the front line (advanced bases). Operational logistics is the link between strategic logistics and tactical logistics. The objective of operational logistics is to ensure that military operations are carried out continuously through all phases of a major operation or campaign. The role of logistics in supporting the operations of the Indonesian Navy cannot be doubted. The success of the Navy's operations begins with the readiness of logistical support because the character of the Navy's defense equipment is full of technology and requires continuous logistical support. Navy operations, both in times of peace and in times of war, require adequate logistical support so that the operations carried out can run smoothly. Logistical support is the backbone of the successful operation of the Navy.

In order to support the combat readiness of defense equipment, especially warships, integration in logistical planning is needed in order to meet the operational needs of Koarmada I. For this reason, the reliability of integrated logistical support must be realized. Only with the reliability of integrated logistical support will the role of logistics be optimal in supporting the operations of the Navy, especially those carried out by Koarmada I. Logistics capability is one of the things that must be fulfilled by the Navy Base. In the context of Koarmada I, the logistical capabilities provided by the base at Pondok Dayung Jetty Jakarta are still inadequate due to various related problems. These problems are as follows: 1) Logistics facilities (Fasharkan, Faslabuh, Fasbek and Fatwatpers) which are not adequate according to the standardization of bases 2) The distance between the operating area (point of consumption) and logistics facilities (point of origin) is quite far 3 ) Limited number and quality of personnel in logistics. Logistics services are related to the organization's ability to provide logistics services to users (consumers) by utilizing available resources. The available resources include human resources and other resources such as budget support, availability of facilities and infrastructure to support the implementation of main tasks and so on. Resource issues have always been one of the key issues in measuring organizational performance, because an organization cannot run without the availability of resources.

The objectives of this research are to analyze the influence of Strategic Human Resources Competence on Organizational Performance, analyze the influence of Logistic Management on Organizational Performance, analyze the influence of Strategic Human Resources Competence on Strategic Leadership, analyze the influence of Logistic Management on Strategic Leadership, analyze the influence of Strategic Leadership on Organizational Performance, analyzing the influence of Strategic Human Resources Competence on Organizational Performance mediated by Strategic Leadership, analyzing the effect of Logistic Management on Organizational Performance mediated by Strategic Leadership

\section{LITERATURE REVIEW}

\section{Strategic Human Resources Competence}

There are five approaches to strategic HRM. It consists of a resource-based strategy (RBV), achieving strategic fit, high-performance management, high-commitment management, and high-involvement management. . Resource-based approach A fundamental goal of a resource-based HR strategy, from Barney's (1991) perspective, is to develop strategic capabilities - achieving a strategic fit between resources and opportunities and gaining added value from the effective deployment of resources. The resource-based approach discusses the method of increasing the company's strategic capabilities with the development of managers and staff. Managers and staff are those who can think and plan strategically and who understand strategic issues. The resource-based approach is based on the belief that competitive advantage is obtained if a company can acquire and develop human resources that enable it to learn faster and apply learning more effectively than its competitors (Hamel and Prahalad, 1989). Human resources referred to by Barney (1995) 
are human resources that include all experience, knowledge, judgment, risk-taking tendencies and individual wisdom related to the company. Kamoche (1996) suggests that in a resource-based view, the firm is seen as a package of tangible and intangible resources, as well as capabilities needed for product/market competition. In line with human capital theory, resource-based theory emphasizes that investment in human resources will add value to the company. Its strategic goal is to create companies that are smarter and more flexible than their competitors (Boxall, 1996). That is by hiring and developing their staff to be more talented and expanding their skill base. Therefore, it is related to the improvement of the company's human or intellectual resources. Ulrich (1998) argues that knowledge has become a direct competitive advantage for firms. So the challenge for organizations is to ensure that they have the ability to compensate and retain the talented individuals they need. When the external environment is in a volatile state, the company's own resources and capabilities will be more stable. Therefore, the ability of HR in the business will last longer than the need (eg market). The unique talents of employees, including superior performance, productivity, flexibility, innovation and capabilities will provide customers with a high level of service. So that competitive advantage based on effective HR management provides an advantage that is difficult to imitate. One of the key competitive advantages is the ability to differentiate providing customer needs more precisely than that provided by its competitors.

HR strategy must be in accordance with the business strategy (vertical fit), and must be an integral part of the business strategy, contributing to the business planning process. Vertical integration is possible to provide a match between business strategy and HR strategy to support previous achievements and help define business strategy. Horizontal integration with aspects other than HR strategy to unite existing differences, with the aim of achieving a compatibility approach in managing HR in various practices by providing support to each other. Spencer and Spencer in Uno (2007) explain that competence is a characteristic that stands out for a person and becomes ways of behaving and thinking in all situations, and lasts for a long period of time. From this opinion, it can be understood that competence refers to a person's performance in a job that can be seen from his thoughts, attitudes, and behavior. Furthermore, Spencer and Spencer in Uno (2007) divide competence into five characteristics, namely as follows; (1) Motives, namely something that people think and want that causes something; (2) Traits, namely physical characteristics of consistent responses to situations; (3) Self-concept, namely attitudes, values, and image of a person; (4) Knowledge, namely information possessed by a person in a particular field; (5) Skills, namely the ability to perform tasks related to physical and mental.

\section{Logistics Management}

The key principle in logistics management is that logistics is an item that is needed so that an activity can run smoothly, to be a good logistics section you must understand the science of logistics management, namely the ability to manage goods through planning actions and determining requirements, procurement, storage , distribution, maintenance and, elimination to achieve the goals that have been set.

According to Rietjens, Kampen and Grant (2016: 97), military logistics is defined as a large organizational business that involves planning, preparing and supplying military material to support the armed forces. Logistics affects the daily activities of the military, exercises, training, mobilization, deployment of forces and progress of battles. Logistics also affects combat capability in wartime and the sustainability of operations in peacetime.

In logistics, one of the concepts developed is the Integrated Logistics Concept (ILC). According to Rietjens, Kampen and Grant (2016:98), the Integrated Logistics Concept (ILC) bridges the gap between the organization's competitive strategy and the logistics components within the organization. In military operations, citing Rietjens, Kampen and Grant (2016:98), competitive strategy is known as mission and the Integrated Logistics Concept (ILC) offers a systematic approach to understanding, analyzing and, where possible, improving logistics performance in operations.

The Integrated Logistics Concept (ILC) starts from the organization's competitive strategy and the logistics objectives derived from the strategy. Quoting Rietjens, Kampen and Grant (2016: 98), to realize the goal, an organization must make decisions in four areas, namely logistics infrastructure, logistics planning and control, logistics information and logistics personnel organization. The implementation of each decision on each of the four components of the logistics concept will determine the logistics performance of an organization. Therefore, logistics performance indicators are a progressive scale to determine the quality of an organization's 
logistics concept. Careful analysis of performance indicators can also provide clues to improvement or adjustment of decision making in each of the four areas.

According to Hartanto (2015:228) the concept of integrated logistics support can be approached with logistics management theory. In the defense sector, the logistics concept has evolved into Integrated Logistics Support (ILS). ILS is defined by Blanchard as all elements of support to ensure the effectiveness and economic value of a system or equipment at every level of maintenance according to the planned life cycle. Quoting Jones, Hartanto (2015:228) states that ILS consists of maintenance planning, manpower and personnel, supply support, support and test equipment, training and training devices, technical documentation, computer resources, packing handling storage and transportation, facilities, reliability and maintainability.

According to Chang, Prior and Gottwalt (2016:107-108), there are three main challenges related to logistics. First, planning and forecasting are difficult and time consuming. Second, data discrepancy. Third, an inventory system that is less anticipatory in the future. These three main challenges are always faced by the military of various countries, because logistics is also related to how to predict what will happen in the future.

Logistics has a close relationship with supply chain management. According to Sethi and Sharma (2018: 197) citing Mentzer, supply chain management is defined as "the systemic, strategic coordination of the traditional business functions and the tactics across these business functions within a particular company and across businesses within the supply chain, for the purposes of improving the long-term performance of the individual companies and the supply chain as a whole". Supply chain management will determine how reliable a management system is owned by an Armed Forces.

\section{Strategic Leadership}

Leadership as the ability to influence a group towards achieving a vision or set of goals. This source of influence may be formal, as provided by managerial rank within an organization (Langton, Robbins and Judge, 2016). Another opinion is conveyed by Colquitt (2015) that leadership is the use of power and influence to direct the activities of followers towards the achievement of goals, power is the ability to influence the behavior of others and resist unwanted influences in return, power is needed, because it gives the leader the ability to influence people. other. Along with the development of leadership theory, strategic management is also known as strategic leadership. According to Witts (2016) strategic leadership is the ability of the top management team to create a vision and mission, think and act strategically, and create organizational competitiveness in a sustainable manner. Regardless of the formal structure of the organization, differences will occur in the extent to which strategic leadership is actually shared among top executives. An organization with an executive team may have an autocratic CEO who allows other executives little influence over strategic decisions, whereas an organization with a traditional hierarchy may have a CEO who empowers other top executives to share responsibility for making strategic decisions (Yulk, 2013).

Strategic leadership includes addressing issues that are usually handled by the company's top management team (Zia-ud-din., Shabbir., Asif., Bilal and Reza, 2017). Emerging strategic leadership abilities remain separate from emerging regulatory skills or emerging leaders with key processes (Stigter and Cooper, 2015). Witts (2016) further explains that strategic leadership is the ability of leaders to imagine and direct organizational actions towards the successful achievement of organizational goals. From the explanation of Yulk (2013) in his empirical findings, several characteristics of strategic leader behavior are stated, namely 1) daring to take decisive action, especially when facing a crisis, 2) having the competence to make lasting changes, 3) knowing what to do and being able to control events/situations, 4) appreciate good performance but do not blame external conditions for poor performance.

Strategic leadership is related to leadership that is able to bring strategic changes to the progress of the company, this can be seen through transformational leadership and transactional leadership (Azbari, Akbari and Chaijani, 2015; Ozer and Tinaztepe, 2014).

\section{Organizational Performance}

Organizational performance can be simply defined as the company's performance compared to goals and objectives (Novak, 2017). Organizational performance also depends on its employees, who are an important part of the organization and form a team that works to achieve organizational goals (Almatrooshi, Singh and Farouk, 2016). Tomal and Jones (2015) define organizational performance as the actual result or output of an organization measured against the organization's intended output. Meanwhile, Bendickson, Gur, and Taylor 
(2018) say that organizational performance contains the effectiveness, efficiency, and satisfaction of every member of the organization in achieving performance. And the performance results are evaluated by management to present the performance results of the implementation and achievement of operational targets of each employee.

Goesaert, Heinz \& Vanormelingen (2015) state that organizational performance is a performance evaluation carried out to physically examine the organization and to evaluate the quality of the organization and the achievement of goals against previous problems by adopting the results of the evaluation of the actions that have been taken, so that the reference is useful for the organization. to improve further operations and resource allocation as well as revise management strategy and plan future directions. In addition, organizational performance becomes a major aspect in many management studies because it plays an important role in developing, implementing, overseeing a strategic plan, and setting goals for the company's future (Teeratansirikool, Siengthai, Badir, and Charoenngam, 2013).

From some of the statements above, it can be concluded that organizational performance is how well a company can improve and achieve its success through the performance of employees, both in terms of finance, sales, and others. The organizational performance measurement index is divided into three dimensions, namely efficiency, effectiveness, and adaptability. Tseng and Lee (2014) state that there are three dimensions in organizational performance, namely as follows:

a. Financial performance, measured based on the company's investment profit, level of sales and company income.

b. Business performance, not only includes financial measurement indexes, but also includes operating performance which includes business market share, product quality, new product introductions, marketing effectiveness, and other non-financial matters.

c. Organizational effectiveness, the measurement used includes the two types of measurement indices above and how the influence of leadership style on organizational performance through trust in employees with various internal conflicts to meet various employee goals, such as employee morale and so on.

According to Koohang, Paliszkiewicz and Goluchowski (2017) there are seven measurement indices in organizational performance, which are as follows:

a. Effectiveness, namely the ability of employees to produce a result in accordance with company goals.

b. Efficiency, namely the ability of employees to complete work with minimal time and effort.

c. Quality, refers to product quality as excellence and the state of the product is free from significant defects, deficiencies, and variations.

d. Productivity, namely the company's ability to produce, create, and improve goods and services.

e. The quality of work life, the opportunity provided by the company to employees to improve their personal life through their work environment and experiences can contribute to the company's competitive advantage.

f. Innovation, is the process of transforming an idea or invention into a product or service that creates value that is very important for the survival of the company.

g. Profitability, namely the company's ability to do more to gain a competitive advantage.

The conceptual framework in this study is as shown in the image below:

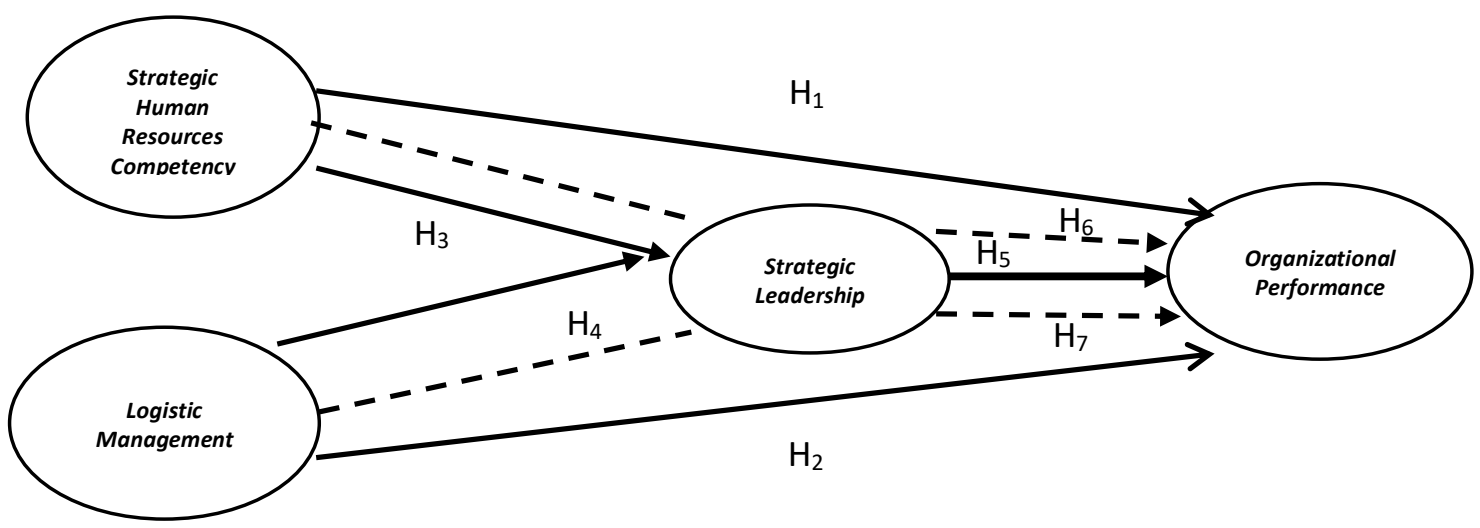


Based on the problem formulation and framework, the hypotheses in this study are: H1: There is a positive influence of Strategic Human Resources Competence on Organizational Performance, H2: There is a positive influence of Logistic Management on Organizational Performance, H3: There is a positive influence of Strategic Human Resources Competence on Strategic Leadership, H4: There is a positive influence of Logistic Management on Strategic Leadership, H5: There is a positive influence of Strategic Leadership on Organizational Performance, H6: There is a positive influence of Strategic Human Resources Competence on Organizational Performance mediated by Strategic Leadership, H7: There is a positive influence of Logistic Management on Organizational Performance mediated by Strategic Leadership

\section{METHODS}

This type of research uses hypothetical causality testing using cross sectional, hypothesis testing is a method of making decisions based on data analysis from controlled and uncontrolled experiments. In statistics, a result can be said to be significant if it is statistically almost impossible for the event to be caused by accidental factors, according to a predetermined probability. Hypothesis testing is also referred to as confirmation of data analysis. Analysis test decisions are almost always made based on the submission of hypothesis 0 . This is a test to answer questions that assume hypothesis 0 is true (Cramer and Howitt, 2004).

Operational Definition and Measurement of Variables

\section{a. Organizational Performance}

Organizational Performance is an indicator that measures how well a company is achieving its goals (Valmohammadi, 2014). The dimensions and indicators of the Organizational Performance variable are as follows.

Dimensions and Indicators of Organizational Performance

\begin{tabular}{lll}
\hline Dimensi & Indikator & Sumber \\
\hline \multirow{2}{*}{$\begin{array}{l}\text { Internal business } \\
\text { process performance }\end{array}$} & Menghasilkan produk berkualitas & Kuo,2013; \\
\cline { 2 - 2 } & Kenghasilkan Produk yang sesuai regulasi & \\
\cline { 2 - 2 } $\begin{array}{l}\text { Financial } \\
\text { performance }\end{array}$ & Menghasilkan produk yang mengesankan & \\
\cline { 2 - 2 } $\begin{array}{l}\text { Customer } \\
\text { performance }\end{array}$ & Pertumbuhan penjualan & Pertumbuhan net profit \\
\cline { 2 - 2 } & Kepuasan customer atas produk & Kepuasan customer atas pelayanan \\
\cline { 2 - 2 } & Loyalitas customer & \\
\hline
\end{tabular}

Source: Processed data, 2020

\section{b. Strategic Human Resource Competency}

Strategic Human Resource Competency is a characteristic that stands out for a person and becomes ways of behaving and thinking in all situations, and lasts for a long period of time. From this opinion, it can be understood that competence refers to a person's performance in a job that can be seen from thoughts, attitudes, and behavior. The dimensions and indicators of the Strategic Human Resource Competency variable are as follows.

Dimensions and Indicators of Strategic Human Resource Competency

\begin{tabular}{|c|c|c|}
\hline Dimensions & Indicators & Source \\
\hline Team Orientation & $\begin{array}{ll}\text { 1. } & \text { Short Term Orientation } \\
\text { 2. } & \text { Long Term Orientation }\end{array}$ & $\begin{array}{l}\text { Miller et al } \\
(2015)\end{array}$ \\
\hline Communication & $\begin{array}{l}\text { 1. Verbal Communication } \\
\text { 2. Non Verbal Communication }\end{array}$ & \\
\hline People Management & 1. People Management & \\
\hline Customer Focus & 1. Customer Focus & \\
\hline Result Orientation & 1. Result Orientation & \\
\hline Problem Solving & 1. Problem Solving & \\
\hline Planning and Organizing & 1. Planning and Organizing & \\
\hline
\end{tabular}




\section{Conceptual Skill}

Leadership

1. Democrative Leadership

2. Participative Leadership

Source: Processed data, 2020

3. Authoritarian Leadership

\section{c. Logistic Management}

Logistics Management is an integrated system that coordinates all processes within the organization/company in preparing and delivering products/goods to consumers. This process includes planning, sourcing of inputs, transformation of raw materials into finished goods, transportation, distribution, warehousing, information systems and payment of goods, until the goods are consumed by consumers and finally product/goods return services. The dimensions and indicators of the Logistics Management variable are as follows.

\begin{tabular}{lll}
\multicolumn{2}{l}{ Dimensions and Indicators of Logistics Management } & \\
\hline Dimensions & Indicators & Source \\
\hline Competitive advantage & Competitive advantage & Yosephyn Patria \\
Use of time and place & Use of time and place & Larici, Fino Wahyudi \\
Delivery speed & Delivery speed & Abdul \\
Company image & Company image & 2019 \\
\hline
\end{tabular}

Source: Processed data, 2020

\section{d. Strategic Leadership}

Strategic leadership is the ability to influence others to voluntarily make day-to-day decisions that enhance the long-term viability of the organization, while at the same time maintaining its short-term financial stability (Serfontein and Hough, 2011).

Dimensions and Indicators of Strategic Leadership

\begin{tabular}{|c|c|c|}
\hline Dimensios & Indicators & Source \\
\hline \multirow{4}{*}{$\begin{array}{l}\text { Transformation } \\
\text { al leadership }\end{array}$} & Develop vision & \multirow{7}{*}{$\begin{array}{l}\text { Chaijani (2015); } \\
\text { Ozer dan } \\
\text { Tinaztepe } \\
(2014)\end{array}$} \\
\hline & Inspirational communication & \\
\hline & Intellectual stimulation & \\
\hline & Supportive leadership & \\
\hline \multirow{3}{*}{$\begin{array}{l}\text { Transactional } \\
\text { leadership }\end{array}$} & Contingent Rewards & \\
\hline & $\begin{array}{l}\text { Focus on errors, exceptions, and deviations from the } \\
\text { standard }\end{array}$ & \\
\hline & Management exception & \\
\hline
\end{tabular}

Source: Processed data, 2020

\section{Population and Sampling}

The population in this study were TNI officers with the rank of Lieutenant Colonel (Letkol) to Rear Admiral (Laksda) at Headquarters and Koarmada I totaling 180 people.

\section{Analysis Models and Data Analysis Techniques}

The steps taken in the process of data analysis, first by tabulating the data. Questionnaires that have been returned by respondents are selected for completeness of filling. Only completely filled out questionnaires are used. The data that has been selected is coded according to the variables and variable classification, and then tabulated using Excel software. The second is the data analysis stage, using the Stuctural Equation Model (SEM) method. The software used for structural analysis is LISREL 8.80.

For testing the proposed hypothesis, the data obtained is then processed according to the needs of the analysis. The data is processed and presented based on the principles of descriptive statistics that will be used for discussion purposes. Meanwhile, for the purposes of analysis and hypothesis testing, an inferential statistical approach is used. SEM analysis using a statistical program that is LISREL 8.80 . 


\section{FINDINGS AND DISCUSSION}

\section{Structural Equation Models and Hypotheses}

Furthermore, the full SEM model of testing the parameter parameter (loading factor/indicator coefficient) will be presented on the exogenous and endogenous models. This test is intended to determine the strength of the indicators of each latent variable (construct).

This analysis measures the $\mathrm{t}$-value and coefficient of structural equations. By testing the $\mathrm{t}$-value is greater than 1.96. The $\mathrm{t}$-value of the coefficients/parameters and the coefficients/parameters (estimates) can be seen in the following figure:

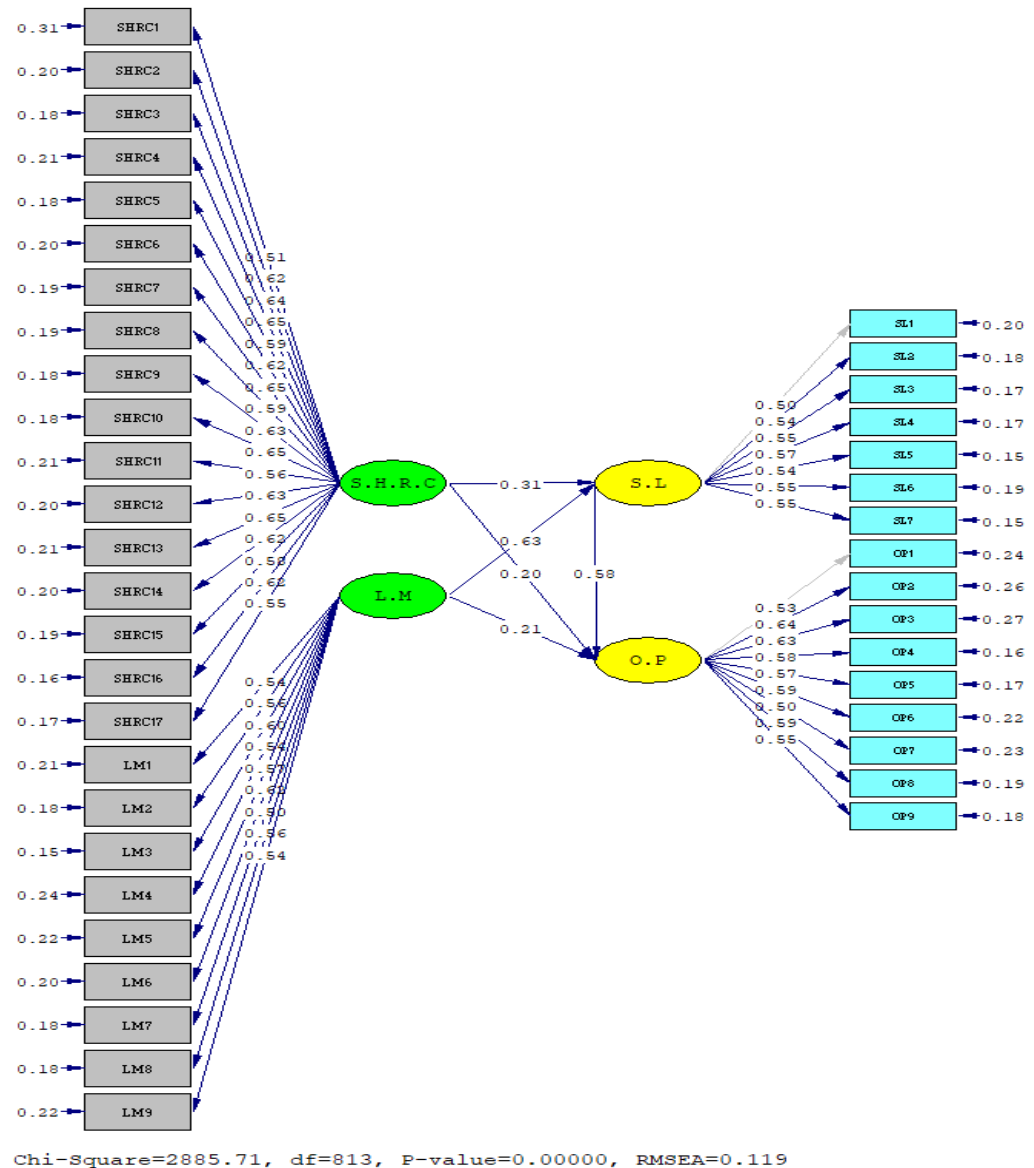

Model Struktural (Estimates)

Source: Processing Results with LISREL 8.80

The model estimates image shows the complete model path diagram with the numbers that are the results of non-standardized estimates. 


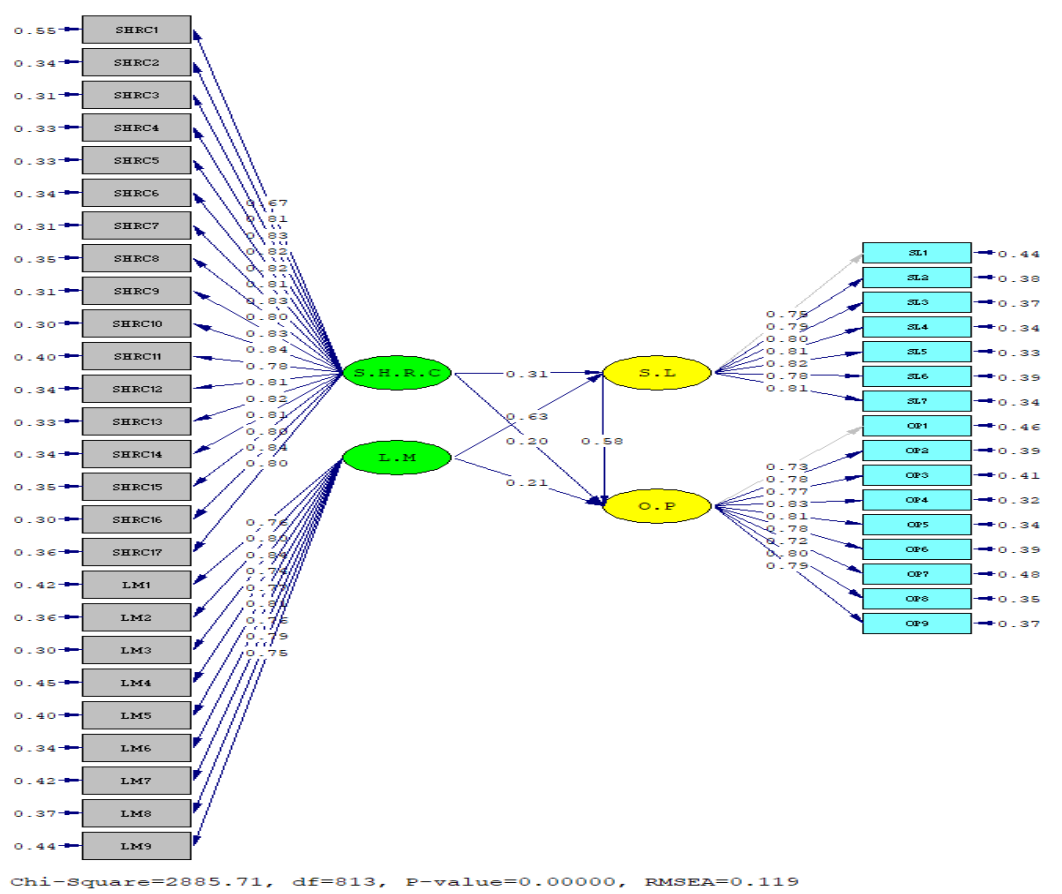

Model Struktural (Standardized Solutions)

Source: Processing Results with LISREL 8.80

The standardized solutions model image shows a complete model path diagram with the numbers that are the standardized estimation results.

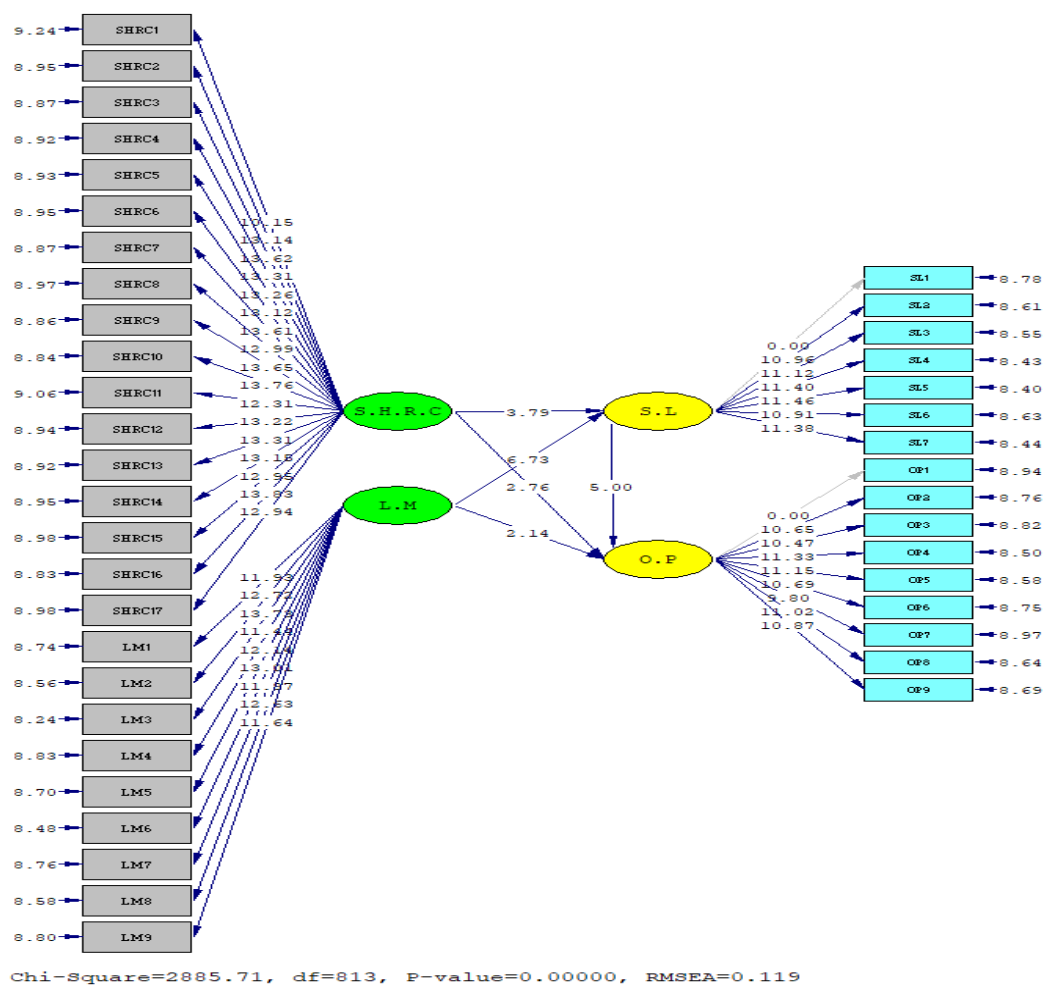

Model Struktural (T Values)

Source: Processing Results with LISREL 8.80

The $\mathrm{t}$-values model image displays a complete model path diagram with numbers showing the $\mathrm{t}$-values of each estimated number. 
On the results of data analysis using the Structural Equation Model (SEM) method and using the LISREL 8.80 application software processing tool, a summary of the model suitability index is obtained as shown in the table below:

Model Fit Index

\begin{tabular}{cccc}
\hline $\begin{array}{c}\text { Goodness } \\
\text { of fit index }\end{array}$ & $\begin{array}{c}\text { Criteria } \\
\text { (cut-off } \\
\text { value) }\end{array}$ & Hasil & Kesimpulan \\
\hline $\begin{array}{c}\mathrm{X}^{2}-\text { Chi- }^{-} \\
\text {square }\end{array}$ & $\begin{array}{c}\text { Diharapkan } \\
\text { kecil }\end{array}$ & \multicolumn{2}{c}{} \\
\hline P - value & $<0,05$ & 0,000 & Model tidak \\
\hline RMSEA & $\leq 0,10$ & 0,119 & Marginal fit \\
\hline NFI & $\geq 0,90$ & 0,90 & Model fit \\
\hline NNFI & $\geq 0,90$ & 0,91 & Model fit \\
\hline CFI & $\geq 0,90$ & 0,92 & Model fit \\
\hline IFI & $\geq 0,90$ & 0,92 & Model fit \\
\hline
\end{tabular}

Source: Processed data

Based on the table above, there are four model suitability indices obtained that have a good model suitability index (good fit), namely: NFI, NNFI, CFI, and IFI. Thus, it can be continued in the next analysis.

Furthermore, based on the pictures above, there are results that contain information about the estimation results of the structural equations or the equations of the structural model. Where in this section relates to the evaluation of the coefficients or parameters that indicate a causal relationship or the influence of one latent variable on another latent variable. The resulting structural model equation is as follows:

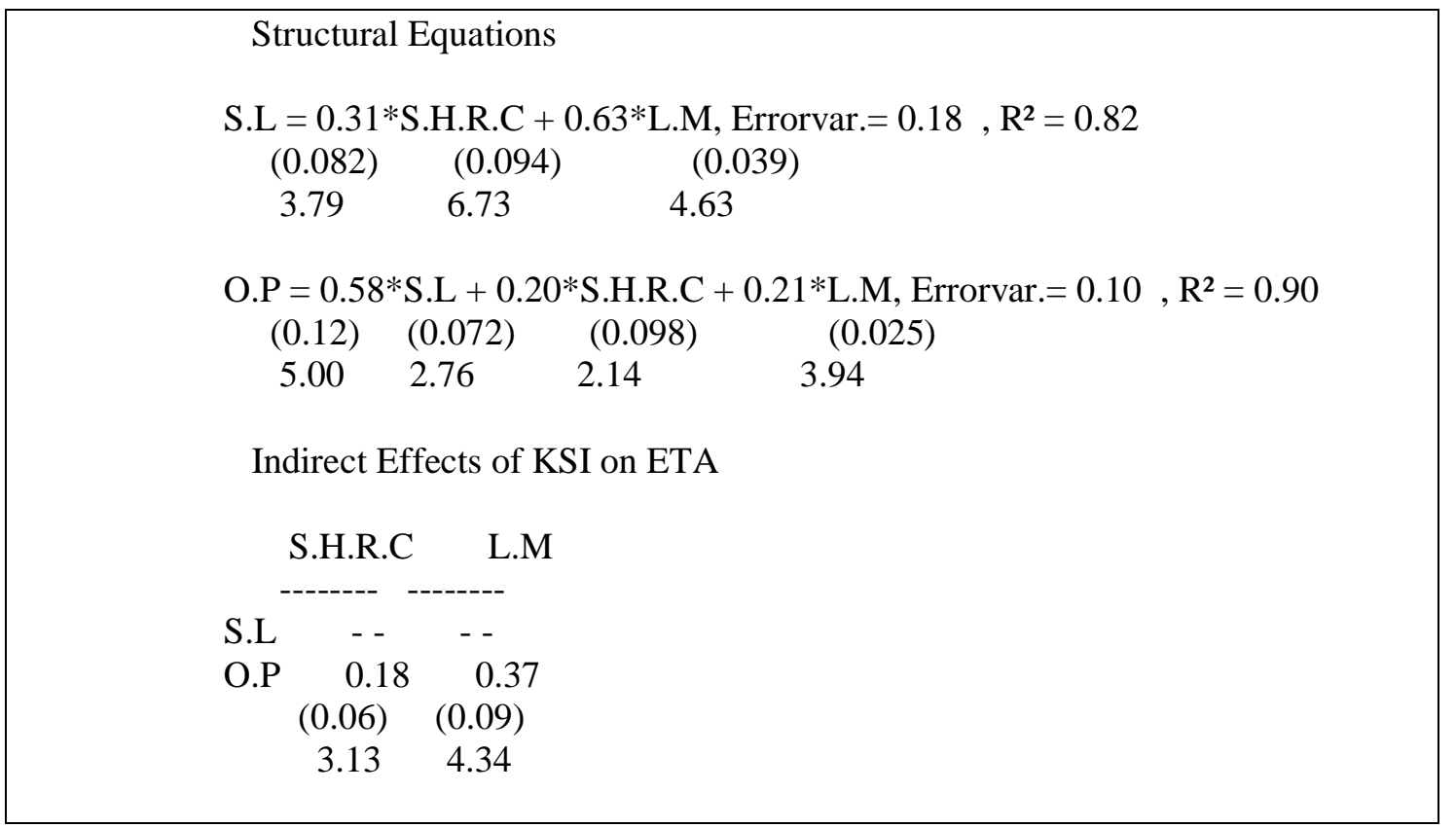

Coefficient or parameter values. This value is a previously estimated value that is used as a comparison of the t-value to test the hypothesis of the study. The results of this evaluation can be summarized in the table below which is accompanied by testing the hypotheses of the research model as follows: 
Structural Model Coefficient Evaluation

\begin{tabular}{|c|c|c|c|}
\hline Path & Estimasi & t-value & Kesimpulan \\
\hline $\begin{array}{l}\text { Strategic Human Resources Competence } \rightarrow \\
\text { Organizational Performance }\end{array}$ & 0.20 & 2.76 & Diterima \\
\hline $\begin{array}{l}\text { Logistic Management } \rightarrow \text { Organizational } \\
\text { Performance }\end{array}$ & 0.21 & 2.14 & Diterima \\
\hline $\begin{array}{l}\text { Strategic Human Resources Competence } \rightarrow \\
\text { Strategic Leadership }\end{array}$ & 0.31 & 3.79 & Diterima \\
\hline Logistic Management $\rightarrow$ Strategic Leadership & 0.63 & 6.73 & Diterima \\
\hline $\begin{array}{l}\text { Strategic Leadership } \rightarrow \text { Organizational } \\
\text { Performance }\end{array}$ & 0.58 & 5.00 & Diterima \\
\hline
\end{tabular}

Source: Processing Results with LISREL 8.80

Calculation Results of the Direct and Indirect Effects of Strategic Human Resources Competence and Logistics Management on Organizational Performance Through Strategic Leadership

\begin{tabular}{|c|c|c|c|c|}
\hline \multirow[t]{2}{*}{ Variabel } & \multicolumn{4}{|c|}{ Besar Pengaruh } \\
\hline & Langsung & $\begin{array}{r}\text { Tidak } \\
\text { Langsung }\end{array}$ & Keterangan & T Value/ F Value \\
\hline $\begin{array}{c}\text { Strategic } \\
\text { Human } \\
\text { Resources } \\
\text { Competence }\end{array}$ & 0.20 & 0.18 & $\begin{array}{c}\text { Melalui } \\
\text { Strategic } \\
\text { Leadership }\end{array}$ & $\begin{array}{c}\mathrm{t}=3.13>1.96 \\
\text { Diterima }\end{array}$ \\
\hline $\begin{array}{c}\text { Logistic } \\
\text { Management }\end{array}$ & 0.21 & 0.37 & $\begin{array}{c}\text { Melalui } \\
\text { Strategic } \\
\text { Leadership }\end{array}$ & $\begin{array}{c}\mathrm{t}=4.34>1.96 \\
\text { Diterima }\end{array}$ \\
\hline
\end{tabular}

Source: Processing Results with LISREL 8.80

\section{Research Discussion}

1. The Influence of Strategic Human Resources Competency on Organizational Performance

Based on the results obtained, it is known that Strategic Human Resources Competence has a direct effect on Organizational Performance with a t-value of 2.76 (t-value > 1.96), which means that hypothesis 1 is accepted. The size of the partial estimate of Strategic Human Resources Competence on Organizational Performance is 0.20 .

The influence of Strategic Human Resources Competence on Organizational Performance is positive and significant. It means that the higher/positive Strategic Human Resources Competence, the higher/positive Organizational Performance means that the more respondents feel that they are able to realize synergy and integration in managing national borders, receive suggestions and input in every problem solving, can resolve any obstacles encountered, and are able to control and influencing others to carry out tasks; the more respondents feel that the company has increased sales volume, the company has been able to achieve high customer loyalty, indicated by repeat purchases and recommendations, and the company can reduce costs for work accidents significantly.

2. Influence of Logistic Management on Organizational Performance

Based on the results obtained, it is known that Logistic Management has a direct effect on Organizational Performance with a t-value of 2.14 ( $\mathrm{t}$-value> 1.96), which means that hypothesis 2 is accepted. The size of the partial estimate of Logistic Management on Organizational Performance is 0.21.

The influence of Logistic Management on Organizational Performance is positive and significant. Means that the higher / positive Logistics Management, the higher / positive Organizational Performance, meaning that the more respondents feel that the impression given by the company in terms of service is very good, the additional services provided by the company are superior to competitors, and the products sold by the company are superior to those of competitors. with competitors; the more respondents feel that the company has increased sales volume, the company has been able to achieve high customer loyalty, indicated by repeat purchases and recommendations, and the company can reduce costs for work accidents significantly. 


\section{The Influence of Strategic Human Resources Competence on Strategic Leadership}

Based on the results obtained, it is known that Strategic Human Resources Competence has a direct effect on Strategic Leadership with a t-value of 3.79 (t-value $>1.96$ ), which means that hypothesis 3 is accepted. The size of the partial estimate of Strategic Human Resources Competence on Strategic Leadership is 0.31 .

The influence of Strategic Human Resources Competence on Strategic Leadership is positive and significant. This means that the higher/positive Strategic Human Resources Competence, the higher/positive Strategic Leadership means that the more respondents feel that they are able to realize synergy and integration in the management of national borders, receive suggestions and input in every problem solving, can resolve any obstacles encountered, and are able to control and influencing others to carry out tasks; the more respondents feel that the leader gives encouragement to employees to seek opportunities from any changes in the work environment, can face challenges in solving problems in a more effective and efficient way, and develop the company's strategic vision for the future.

4. Influence of Logistic Management on Strategic Leadership

Based on the results obtained, it is known that Logistic Management has a direct effect on Strategic Leadership with a t-value of 6.73 (t-value $>1.96$ ), which means that hypothesis 4 is accepted. The size of the partial estimate of Logistic Management on Strategic Leadership is 0.63.

The influence of Logistic Management on Strategic Leadership is positive and significant. This means that the higher/positive Logistics Management, the higher/positive Strategic Leadership means that the more respondents feel that the impression given by the company in terms of service is very good, the additional services provided by the company are superior to competitors, and the products sold by the company are superior to those of the company. competitors; the more respondents feel that the leader gives encouragement to employees to seek opportunities from any changes in the work environment, can face challenges in solving problems in a more effective and efficient way, and develop the company's strategic vision for the future.

5. The Influence of Strategic Leadership on Organizational Performance

Based on the results obtained, it is known that Strategic Leadership has a direct effect on Organizational Performance with a t-value of 5.00 (t-value >1.96) which means that hypothesis 5 is accepted. The size of the partial estimate of Strategic Leadership on Organizational Performance is 0.58.

The influence of Strategic Leadership on Organizational Performance is positive and significant. It means that the higher/positive Strategic Leadership, the higher/positive Organizational Performance, meaning that the more respondents feel that the leader provides encouragement to employees to seek opportunities from any changes in the work environment, can face challenges in solving problems in a more effective and efficient way, and develop the company's strategic vision for the future; the more respondents feel that the company has increased sales volume, the company has been able to achieve high customer loyalty, indicated by repeat purchases and recommendations, and the company can reduce costs for work accidents significantly.

6. The Influence of Strategic Human Resources Competency on Organizational Performance mediated by Strategic Leadership

Based on the results obtained, it is known that the indirect influence of Strategic Human Resources Competence on Organizational Performance through Strategic Leadership is 0.18 and the t-value is 3.13 (t-value > 1.96), which means that hypothesis 8 is accepted. The mediating effect of Strategic Leadership between Strategic Human Resources Competence and Organizational Performance is positive and significant. This means that the higher/positive Strategic Leadership, the stronger the influence of Strategic Human Resources Competence on Organizational Performance, meaning that the more respondents feel that the leader gives encouragement to employees to seek opportunities from any changes in the work environment, can face challenges in solving problems in a more effective way. and efficient, and develop the company's strategic vision for the future; it will further strengthen to be able to realize synergy and integration in the management of state borders, receive suggestions and input in solving any problems, be able to resolve any obstacles encountered, and be able to control and influence others to carry out their duties; so that in the end the company has increased sales volume, the company has been able to achieve high customer loyalty, indicated by repeat purchases and recommendations, and the company can reduce costs for work accidents significantly.

7. Influence of Logistic Management on Organizational Performance mediated by Strategic Leadership 
Based on the results obtained, it is known that the indirect effect of Logistic Management on Organizational Performance through Strategic Leadership is 0.37 and the $t$-value is 4.34 (t-value > 1.96), which means that hypothesis 9 is accepted. The mediating effect of Strategic Leadership between Logistic Management and Organizational Performance is positive and significant. It means that the higher/positive Strategic Leadership, the stronger the influence of Logistic Management on Organizational Performance, meaning that the more respondents feel that ....; it further strengthens the impression given by the company in terms of excellent service, additional services provided by the company are superior to competitors, and the products sold by the company are superior to competitors; so that in the end the company has increased sales volume, the company has been able to achieve high customer loyalty, indicated by repeat purchases and recommendations, and the company can reduce costs for work accidents significantly.

In addition to the seven main findings based on the proposed hypothesis, the authors also found several important findings that can be used as references or literature for further researchers who are interested in studying the interrelationships of several variables such as: Strategic Human Resources Competence, Logistics Management, Strategic Leadership and Organizational Performance. The relationship between the variables of Strategic Human Resources Competence, Logistic Management, Strategic Leadership and Organizational Performance can be hypothesized and tested either partially, directly, mediated or simultaneously.

\section{CONCLUSION AND RECOMMENDATION}

The general conclusion of this research is that there is an influence of Strategic Human Resources Competence and Logistic Management on Organizational Performance mediated by Strategic Leadership and the seven hypotheses proposed are all proven to be accepted. Strategic Leadership plays a very important role as a mediation in increasing the influence of Strategic Human Resources Competence and Logistics Management on Organizational Performance. Based on the results of hypothesis testing and the discussion in the previous chapter, it can be concluded several research results as follows:

1. There is a positive and significant influence of Strategic Human Resources Competence on Organizational Performance. This shows that improving the effectiveness of Strategic Human Resources Competence will result in increased Organizational Performance.

2. There is a positive and significant effect of Logistic Management on Organizational Performance. This shows that improving the effectiveness of Logistics Management will result in increased Organizational Performance.

3. There is a positive and significant influence of Strategic Human Resources Competence on Strategic Leadership. This shows that improving the effectiveness of Strategic Human Resources Competence will result in increased Strategic Leadership.

4. There is a positive and significant effect of Logistic Management on Strategic Leadership. This shows that improving the effectiveness of Logistics Management will result in increased Strategic Leadership.

5. There is a positive and significant influence of Strategic Leadership on Organizational Performance. This shows that improving the effectiveness of Strategic Leadership will result in increased Organizational Performance.

6. There is an influence of Strategic Human Resources Competence on Organizational Performance which is mediated by This shows that positively improving the effectiveness of Strategic Leadership will lead to an increase in the influence of Strategic Human Resources Competence on Organizational Performance indirectly

7. There is an influence of Logistic Management on Organizational Performance mediated by Strategic Leadership. This shows that positively improving the effectiveness of Strategic Leadership will indirectly increase the influence of Logistic Management on Organizational Performance

\section{Suggestions for Further Research}

Taking into account the various limitations of this study, the researcher provides suggestions for further research, including:

1. Adding qualitative research to deepen the conclusions obtained from the quantitative research results that have been obtained. 
2. Adding linkages with other variables, apart from Strategic Human Resources Competence, Logistics Management, Strategic Leadership and Organizational Performance, such as: commitment, job satisfaction, job stress, role conflict.

\section{REFERENCES}

Ade Supandi, "Development of the Navy's Strength in Support of Indonesia's Vision as a World Maritime Axis". Defense Journal, August 2015, Vol.5 Number 2

Andrej Bujak. "The Development of the Concept of Supply Chain Management As An Example of the Evolution of Logistics". The Wroclaw School of Banking Research Journal, Volume 15, No.1 2015

Arawati Agus, "Supply Chain Management and Competitive Differentiation". International Business Managements Journals, Vol.9. No.5, 2015

Bas Rietjens, Ton van Kampen and Tim Grant, Logistics Planning and Control: Lesson Learned in Afghanistan, in Joseph Soeters, Paul C. Van Fenema and Robert Beeres (et.all). Managing Military Organizations: Theory and Practice. London: 2010, Routledge

Beni Ahmad Saebani and Yana Sutisna. Research methods. Bandung: 2018, Librarian Faithful Publisher

Butje Tampi. "Natuan Islands Conflict between Indonesia and China (A Juridical Study)". Journal of Law Unsrat, Vol.23, No.10, April-December 2017

Cholid Nurboko and Abu Achmadi. Research methodology. Jakarta: 2012, Earth Literacy Publisher

Dharma Agung S.I. and Hollanda Arief K, "Organizing Naval Bases to Strengthen Indonesian Maritime Sovereignty". Journal of Diplomacy and Security Studies, Vol.9, Number 1 (2017)

Dicky R. Munaf and Susanto. Marine Security and Safety Control Command. Jakarta: 2015, Gramedia Main Library

Elizabeth Chang, Daniel D. Prior, and Florian Gottwalt, "Toward an Integrated System for Army Logistics Management", Australian Army Journal, Spring, Vol. XII, No. 2, 2016

I. Wibowo and Syamsul Hadi (et.all). Embrace China. Jakarta: 2009, PT Gramedia Pustaka Utama

Iman Ghozali, Structural Equation Modeling: Alternative Method with Partial Least Squares. Semarang:2014, Undip Publishing Agency

Jonathan Sarwono. Research Strategy. Yogyakarta: 2013, Publisher Andi

Lijan Poltak Sinambela. Human Resource Management. Jakarta: 2019, Earth Literacy Publisher

Manual for the Standardization of Navy Base Administration (PUM-7.03) 2013

Marsetio. SeaPower Indonesia. Jakarta: 2014, Defense University

NATO Headquarters. NATO Logistics Handbook. Brussels: 2012, NATO

Naval Headquarters. Hydro Oceanography White Paper. Jakarta: 2018, Naval Hydro Oceanography Center

Okol Sri Suharyo and Joko Purnomo, "Application of the Analytic Method Process (ANP) in Determining the Priority of Lanal Development (Navy Base) To Become Lantamal (Navy Main Base)". Journal of Systems and Operations Analyst, Vol.3 (2015)

P.J. Vlok, "Supply Chain Management: A Framework of Understanding". South African Journal of Industrial Engineering, November 2014, Volume 25, Issue 3

Philip Kotler. Marketing Management: Millennium Edition. Upper Saddle River, New Jersey: 2000, PrenticeHall Inc

Presidential Decree No. 33 of 1982 concerning Coordination of Planning and Development of Teluk Ratai as the Main Base of the Western Territory of the Navy

Presidential Regulation No. 66 of 2019 concerning TNI Organization General Publication of the Navy (PUM1.03)

Putu Yoga Arsana et al, "Model of Maritime Security Synergy by Naval Bases at Chokepoint Lombok Strait", Proceedings of the 4th National Marine and Fisheries Seminar 2018

Ricky Virona Martono. Logistics Management. Jakarta: 2019, PT Gramedia Pustaka Utama

Sanjay Sethi and Sunil Sharma, "Performance Measurement of Military Supply Chains", International Journal of Engineering and Management Research, Vol.8, Issue 2, April 2018

Sedarmiyanti, Human Resource Management: Bureaucratic Reform and Civil Service Management. Bandung: 2019, PT Refika Aditama

Sisriadi, "Development of Military Defense Posture to Support the Realization of the World Maritime Axis". Wira, Volume 59, No.43, March-April 2016

Sopiah and Etta Mamang Sangadji. Strategic Human Resource Management. Yogyakarta: 2018, Publisher Andi Syaiful Anwar. Protect the Country. Jakarta: 2016, Indonesian Torch Library Foundation 
Tedjo Edhy Purdijatno. Controlling Maritime Borders. Jakarta: 2010, Grasindo

Yusa Adi Hartanto, "Logistics Management in Improving Alutsista Readiness Indonesian Navy". Defense Journal, April 2016, Vol.6, Number 1 